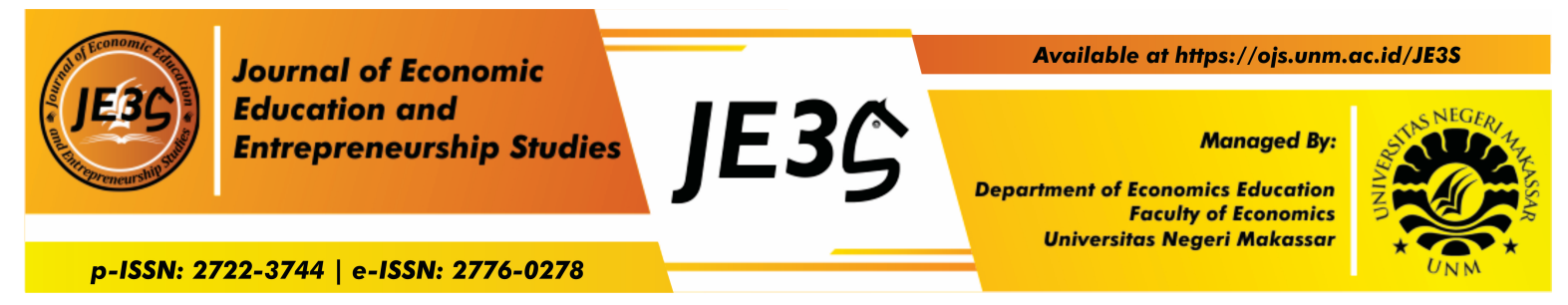

\title{
Analisis Dampak Penggunaan E-Commerce dalam Meningkatkan Omzet Penjualan Usaha Mikro Kecil Menengah di Kota Makassar
}

\author{
Muhammad Ikhsan ${ }^{1 *}$, Muhammad Hasan ${ }^{2}$ \\ ${ }^{1,2}$ Universitas Negeri Makassar
}

\begin{tabular}{l}
\hline Article History \\
\hline Received May 29, 2020 \\
Approved June 17, 2020 \\
Published June 30, 2020 \\
\\
\hline Keywords \\
\hline E-Commerce, Omzet, UMKM
\end{tabular}

\begin{tabular}{c}
\hline JEL Classification \\
\hline M21, L26 \\
\hline
\end{tabular}

\begin{tabular}{l} 
How to Cite \\
\hline Ikhsan, M., \& Hasan, M. 2020. Analisis \\
Dampak Penggunaan E-Commerce \\
dalam Meningkatan Omzet Penjualan \\
UMKM di Kota Makassar. Journal of \\
Economic Education and \\
Entrepreneurship Studies, 1(1), 39-46.
\end{tabular}

\begin{abstract}
This study aims to determine what are the impar of using E-Commerce in increasing MSME sa turnover. This study uses a qualitative approa that is descriptive analysis. The data collecti techniques used are observation, interview a documentation techniques. The research subjer were 5 MSME actors in the city of Makassar. T results showed that there are two impacts of usi E-Commerce, namely positive impacts a negative impacts. The positive impact is the use E-Commerce, namely, the store can be accessed hours, provides security and convenience in $t$ transaction process, eases promotions so that can help communicate faster with customers a can access the global market and can sati: customers and of course can increase sa turnover. Meanwhile, the negative impact is thai the goods are damaged, the goods can be check and result in losses in shipping and packing cos the number of rivals, admin fees charged to buyt and sellers, the COD system that makes sellers $f_{6}$ disadvantaged because the funds are released afi the goods arrive.
\end{abstract}

Muhammad Ikhsan

Jl. Pampang II Lr. 5 No. 5

Makassar, Sulawesi Selatan, Indonesia, Kode Pos 90231

e-mail: muh.ikhsn019@gmail.com

(C) 2020 Universitas Negeri Makassar

\section{PENDAHULUAN}

Pemberdayaan usaha mikro, kecil dan menengah (UMKM) merupakan langkah yang strategis dalam meningkatkan dan memperkuat dasar kehidupan perekonomian dari sebagian besar rakyat Indonesia. Pemberdayaan UMKM diarahkan untuk membangun kemandirian dan daya saing melalui penciptaan iklim usaha yang kondusif, penerapan 
iptek, dan penguatan skala ekonomi. Pemberdayaan UMKM juga digunakan untuk meningkatkan kontribusinya dalam meningkatkan perekonomian baik dalam penanggulangan kemiskinan dan pencipataan lapangan pekerjaan (Anonimius, 2015).

Selain itu perkembangan peran UMKM yang besar ditunjukkan oleh banyaknya jumlah unit usaha serta kontribusinya dalam penyerapan tenaga kerja. Disamping memiliki peranan yang signifikan terhadap perekonomian, Di era globalisasi saat ini UMKM harus mampu menghadapi tingginya persaingan usaha dan tantangan global, seperti meningkatkan inovasi produk dan jasa, pengembangan sumber daya manusia dan teknologi, serta perluasan area pemasaran. Selain itu ada permasalahan klasik yang selalu dihadapi UMKM. Permasalahan tersebut antara lain masalah modal (baik awal, modal operasional, dan modal untuk kebutuhan investasi jangka panjang), kesulitan pemasaran serta keterbatasan sumberdaya manusia (Hendriani, 2012).

Pemanfaatan teknologi informasi khususnya sistem E-Commerce dianggap sebagai salah satu solusi yang dapat digunakan untuk membantu peningkatan dan perkembangan UMKM. Faktor penting dalam penggunaan E-Commerce adalah untuk meningkatkan kemampuan mendapatkan feedback dari pelanggan secara cepat, disamping itu juga bisa menghemat biaya untuk pemasaran. Tanpa pemanfaatan sistem E-Commerce diyakini bahwa UMKM akan melemah dalam pemasarannya. Fatmariani (2011) dalam penelitiannya menunjukkan bahwa semakin tinggih adopsi teknologi informasi sistem E-Commerce dalam UMKM, maka semakin tinggi pula kinerja dari UMKM tersebut. Penelitian lain yang dilakukan Sevtian (2011) menunjukkaan besarnya pengaruh secara simultan antara $E$-Commerce terhadap volume penjualan sebesar $90,9 \%$ dan sisanya dipengaruhi faktor yang lain. Penelitian lain yang dilakukan oleh Maryama (2013) mengemukakan manfaat terbesar dari pemanfaatan $E$-Commerce adalah meningkatkan omzet penjualan sebesar $31 \%$. Karagozoglu dan Lindell (2004) mengemukakan bahwa E-Commerce memiliki dampak positif pada pengembangan basis pelanggang (fungsi pemasaran) dan tidak berdampak signifikan pada manajemen pembelian.

Kementrian komunikasi dan informatika (Kominfo) menyatakan hinggah saat ini masi banyak usaha mikro, kecil dan menengah (UMKM) yang belum bergabung dengan $E$-Commerce. Dari 58 juta UMKM yang ada di Indonesia, UMKM yang bergabung dengan E-Commerce baru sebanyak 8 juta. Angka ini setara dengan 14\%. Kepala Dinas koperasi dan UMKM sulsel Malik Faisal mengatakann bahwa jumlah UMKM disulsel yang terdata mencapai 916.232 unit. Dari jumlah tersebut, $86 \%$ atau 797.081 unit diantaranya masi masuk kategori usaha mikro. UMKM di Sulsel, didominasi oleh sector perdagangan, sementara untuk sektor produksi, jumlahnya sebanyak 108.785 unit. "khusus untuk UMKM yang bergerak di sector makanan dan minuman, persentase jumlahnya berkisar $65 \%$.

Memasuki era 4.0, usaha mikro, kecil, dan menengah (UMKM) seolah dituntut untuk mengembangkan daya saing melalui pemanfaatan platform digital tidak terkecuali bagi pelaku UMKM Kota Makassar. Sayangnya, masi 10\% dari ekosistem pada segmen berklasifikasi UMKM yang baru memanfaatkan teknologi dalam menunjang kegiatan usahanya. Terbatasnya sumber daya penunjang pengembangan kapasitas berbasis digital menjadi salah satu kendalanya termasuk pada aspek permodalan, promosi hingga penguatan kualitas produk yang memiliki daya saing. Merujuk pada data dinas koperasi dan UMKM kota Makassar, jumlah pelaku UMKM sejauh ini sebanyak 16.492 yang bergerak pada beragam sektor.

Electronic commerce (E-Commerce) merupakan konsep yang bisa digambarkan sebagai proses jual beli barang pada internet, atau proses jual beli pertukaran produk, jasa, dan informasi melalui jaringan informasi termasuk internet (Suyanto, 2003). 
Pendapat lain oleh Grandon dan Pearson (2004), mendefinisikan E-Commercesebagai proses jual beli produk atau jasa jaringan data elektronik melalui internet. Lebih lanjut dikemukakan oleh Turban (2004), mendefiniskan E-Commerce sebagai proses jual beli atau pertukaran (exchange) barang, jasa dan informasi dengan menggunakan media jaringan komputer.

\section{METODE}

Dalam penelitian ini, peneliti menggunakan pendekatan kualitatif dengan metode kualitatif deskriptif. Penelitian kualitatif mempergunakan data yang dinyatakan secara verbal dan kualifikasinya bersifat teoretis. Metode kualitatif deskriptif mempelajari masalah-masalah yang ada serta tata cara kerja yang berlaku. Penelitian deskriptif kualitatif ini bertujuan untuk mendeskripsikan apa-apa yang saat ini berlaku. Di dalamnya terdapat upaya mendeskripsikan, mencatat, analisis dan menginterpretasikan kondisi yang sekarang ini terjadi atau ada. Teknik pengumpulan data yang digunakan adalah teknik observasi, wawancara dan dokumentasi. Subjek penelitian berjumlah 5 orang pelaku UMKM yang ada di kota Makassar.

\section{HASIL DAN PEMBAHASAN}

Berdasarkan hasil wawancara bahwa dampak positif dengan adanya pengguanaan $E$ Commerce yaitu, toko yang dapat diakses 24 jam, memberikan keamanan dan kemudahan dalam proses tranksaksi, mempermuda promosi sehingga dapat membantu komunikasi lebih cepat dengan pelanggan dan dapat mengakses pasar global serta dapat memuaskan pelanggan dan tentunya dapat meningkatkan omzet penjualan. Selanjutnya erdasarkan hasil wawancara bahwa dampak negative dengan adanya penggunaan $E$-Commerce yaituapabila barang yang dipesan rusak barang bisa di cancel dan mengakibatkan adanya rugi pada ongkos kirim dan packing, banyaknya saingan sehinggah konsumen akan lebih teliti dalam memilih produk baik dari sisi harga ataupun dari segi kualitasnya, adanya biaya admin yang dibebankan kepada pembeli dan penjual serta dengan adanya berbagai cara yang mudah dan sederhana yaitu adanya cara COD dalam proses pembayaran menguntungkan pembeli tapi dari sisi lain penjual merasa dirugikan karena dana dilepas setelah barang tiba ditangan konsumen. Omzet yang dimaksud dalam penelitian ini adalah omzet penjualan yang berhasil diperoleh perusahaan perbulan. Sesuai dengan teori Chaniago (2002), yang mengatakan bahwa keseluruhan jumlah pendapatan yang didapat dari hasil penjualan suatu barang atau jasa dalam kurung waktu tertentu. Adapun omzet penjualan dari hasil wawancara dapat dilihat pada Tabel 1. 
Tabel 1. Omzet Penjualan

\begin{tabular}{|c|c|c|c|c|}
\hline No. & Nama & Nama usaha & $\begin{array}{c}\text { Omzet sebelum } \\
\text { menggunakan } \\
E \text {-Commercel } \\
\text { bulan }\end{array}$ & $\begin{array}{c}\text { Omzet setelah } \\
\text { menggunakan } \\
E^{-} \\
\text {Commerce/bulan }\end{array}$ \\
\hline 1. & Abdul Wahab & $\begin{array}{l}\text { Rumah Bumbu } \\
\text { Ratna }\end{array}$ & $4-5$ juta & 4,8 juta- 6 juta \\
\hline 2. & $\begin{array}{l}\text { Hasryanty } \\
\text { Achmad }\end{array}$ & $\begin{array}{l}\text { Beauty Shop } \\
\text { Makassar }\end{array}$ & 4-5 juta & 5,2 juta $-6,5$ juta \\
\hline 3. & Hendra & Dygrah Computer & 7,5 juta & 20 juta \\
\hline 4. & Sry Mulya & Hijab Fashion Shop & 1 juta & 1,2 juta \\
\hline 5. & Siti Nur Fajriani & Any Outfit & $6-20$ juta & 7,5 juta- 25 juta \\
\hline
\end{tabular}

Sumber: Olah data, 2020

\section{Dampak Positif}

Sesuai dengan hasil wawancara dampak positif yang pertama dengan adanya penggunaan $E$-Commerce yaitu toko dapat diakses 24 jam hal ini relevan dengan teori E. Turban (2012), yang mengemukanakan bahwa $E$-Commerce memiliki manfaat dan kelebihan bagi berbagai pihak yakni:

a. Bagi perusahaan

- Ketersediaan pasar nasional dan internasional.

- Penurunan biaya internasional, distribusi dan penarikan infomasi.

b. Bagi masyarakat:

- Akses kesejumlah besar produk dan jasa tanpa batas, 24 jam sehari

- Memberikan layanan informasi dengan mudah dan nyaman, kepada orangorang di kota, desa dan berbagai Negara.

Selanjutnya dampak postif dengan adanya penggunaan E-Commerce yaitu memberikan keamanan dan kemudahan dalam proses tranksaksi, dimana dampak ini dirasakan diantaranya dapat menghemat biaya promosi dan meningkatkan kecepatan bertransaksi. Hal ini pada akhirnya akan dapat meningkatkan daya saing bagi UMKM (Mastisia, 2019). Lebih lanjut penggunaan E-Commerce tentunnya dapat membantu mengurangi biaya yang dikeluarkan serta dapat menyampaikan informasi secara detail mengenai produk maupun harga spesial yang diberikan kepada konsumen secara online dan memudahkan proses tranksaksi tanpa harus datang ketoko secara langsung sehingga dapat bersaing dengan toko sejenis dan mendapatkan hasil yang lebih maksimal (Maulana et al, 2015)

Selain dampak positif yang dirasakan oleh pelaku UMKM adalah pendapatan mereka semakin meningkat, produk mereka akan semakin muda dikenal oleh konsumen sehinggah memudahkan dalam mendapatkan pelanggan sesuai dengan hasil wawancara bahwa dampak positif selanjutnya yaitu, mempermuda promosi sehingga dapat membantu komunikasi lebih cepat dengan pelanggan dan dapat mengakses pasar global serta dapat memuaskan pelanggan dan tentunya dapat meningkatkan omzet penjualan. Hal ini relevan dengan teori Spicaalsmilia dan Robahi (2007), yang menunjukkan bahwa yang menjadi manfaat terbesar penggunaan $E^{-}$ Commerce pada perusahaan adalah dapat meningkatkan omzet penjualan dengan persentase sebesar $31 \%$, manfaat berikutnya adalah peningkatan jumlah pelanggan dengan persentase sebesar $25 \%$ dan yang berikutnya adalah perluasan jangkauan 
bisnis serta sarana promosi dengan 16\% serta peluang terbukanya bisnis baru dan kepuasan pelanggan dengan persentase sama yaitu 5\% serta yang terakhir adalah kemudahan hubungan relasi yaitu hanya $2 \%$.

Lebih lanjut pemanfaatan teknologi informasi khususnya sistem e-ecommerce bisa memberikan dampak positif terhadap UMKM dalam hal pemasaran dan operasi. Sesuai dengan teori Karagozoglu dan Lindell (2004), mengemukakan bahwa $E$ Commerce memiliki dampak positif pada pengembangan basis pelanggang (fungsi pemasaran) dan tidak berdampak signifikan pada manajemen pembelian. Sedangkan menurut love dan Irani (2004) mengemukakan bahwa $E$-Commerce membantu UMKM bisa mengetahui manfaat dalam operasi, yaitu untuk membantu meningkatkan kinerja secara keseluruhan. Dengan demikian UMKM akan mendapat keuntungan dalam hal mempromosikan usahanya dan juga dapat memperluas bisnis secara global untuk memperluas jaringan bisnisnya.

\section{Dampak Negatif}

Sesuai dengan hasil wawancara dampak negatif yang pertama dengan adanya penggunaan E-Commerce yaitu apabila barang yang di pesan rusak barang bisa di cancel dan mengakibatkan adanya rugi pada ongkos kirim dan packing, sehingga hal ini bisa mengakibatkan kerugian bagi pelaku usaha UMKM dimana kesalahan ini diakibatkan oleh faktor manusia atau kesalahan sistem. Hal ini sesuaidengan teori Agung (2015), mengatakan bahwa kerugian yang tidak terduga disebabkan oleh gangguan yang dilakukan dengan sengaja, ketidakjujuran, praktek bisnis yang tidak benar, kesalahan faktor manusia atau kesalahan sistem. Adapun dampak negatif menurut Agung (2015), yaiu:

a. Kehilangan segi finansial secara langsung karena kecurangan. Seorang penipu mentransfer uang dari rekening satu ke rekening lainnya atau diatelah mengganti semua data finansial yang ada.

b. Pencurian informasi rahasia yang berharga. Gangguan yang timbul bisa menyingkap semua informasi rahasia tersebut kepada pihak-pihak yang tidak berhak dan dapat mengakibatkan kerugian yang besar bagi si korban.

c. Kehilangan kesempatan bisnis karena gangguan pelayanan. Kesalahan ini bersifat kesalahan non-teknis seperti aliran listrik tiba-tiba padam.

d. Penggunaan akses ke sumber oleh pihak yang tidak berhak. Misalkan seorang peretas program (hacker) yang berhasil membobol sebuah sistem perbankan lalu memindahkan sejumlah rekening orang lain ke rekeningnya sendiri.

e. Kehilangan kepercayaan dari para konsumen. Ini karena berbagai macam faktor seperti usaha yang dilakukan dengan sengaja oleh pihak lain yang berusaha menjatuhkan reputasi perusahaan tersebut.

f. Kerugian yang tidak terduga. Disebabkan oleh gangguan yang dilakukan dengan sengaja, ketidakjujuran, praktek bisnis yang tidak benar, kesalahan faktor manusia atau kesalahan sistem.

Kemudian selanjutnya yaitu banyaknya saingan sehinggah konsumen akan lebih teliti dalam memilih produk baik dari sisi harga ataupun dari segi kualitasnya, dimana dengan banyaknya pelaku usaha mengakibatkan terciptanya banyak kompetitor sehingga pelaku usaha dituntut untuk mencipakan inovasi yang lebih baik dari pesaingnya agar mampu mempertahankan usahanya dan terkhusus pelanggannya, selain itu bentuk persaingan yang sering terjadi adalah masuknya pendatang baru, ancaman produk pengganti, kekuatan tawar menawar pemasok dan 
persaingan antar pesaing. Hal ini mencerminkan bahwa ancaman persaingan tidak hanya sebatas pada sesama perusahaan dalam industry yang ada, tetapi juga datang dari pelanggan, pemasok, produk pengganti serta pendatang baru potensial (Mastisia, 2019). Lebih lanjut Hal ini sesuai dengan teori Rahmidani (2015) kompetisi yang ketat bagi supplier/vendor.

Berikutnya yaitu adanya biaya admin yang dibebankan kepada pembeli dan penjual, Pernyataan tersebut relevan dengan teori Rahmidani (2015), yang mengatakan bahwa pengguna dikenai biaya transaksi dan biaya implementasi atau advertensi dapat menjadi tinggi. Dimana dalam hal ini masing-masing $E$-Commerce memiliki biaya admin yang berbeda-beda. Untuk shoppe biaya adminnya mememiliki tiga tingkatan sesuai dengan statusnya yaitu, yang pertama Seller merupakan sebuah status yang biasa dugunakan bagi para penjual yang baru memulai menjual dishopee dimana biaya adminnya = (harga asli produk-diskon produk dan/atau voucher diskon ditanggung penjual) $\mathrm{x} 0,5 \%$. Selanjutnya Star Seller yaitu penjual yang telah memenuhi kriteria dan telah ditetapkan dishopee dimana biaya adminnya yaitu = (Harga asli produk-diskon produk dan/atau voucher diskon ditanggung penjual)x1.5\%.kemudian yang ketiga yaitu Shopee Mall yang merupakan jenis seller atau status tertinggi bagi penjual dishopee untuk saat ini, untuk mendapatkan status semacam ini, aka nada beberapan hal yang sangat penting dipersiapkan yaitu syaratnya adalah Sertifikat Hak Kekayaan Intelektuan yang ada dalam bentuk sertifikat merk atau merk dagang. Dimana biaya adminnya = (Harga asli produk Diskon produk dan/atau voucher diskon ditanggung oleh penjual shopee mall) x 5\%, selanjutnya yaitu Tokopedia memiliki biaya admin berdasarkan jenis toko, dimana jenis tokonya yaitu Official Store yang berhak menggunakanlima admind toko secara gratis, Power Merchant bias menggunakan 1 admin Toko secara gratis dan terakhir yaitu Reguler Merchant yang akan dikenakan biaya jika menggunakan admind toko, untuk biayanya yaitu 150 ribu/3 bulan. Kemudian untuk biaya admin tranksaksi mitra buka lapak dihilangkan terhitung kamis, 9 mei 2019, dimana biaya admin sebesar 5\% pada tranksaksi mitra bukalapak.

Terakhir mengenai dampak negative dari penggunaan $E$-Commerce yaitu dengan adanya berbagai cara yang mudah dan sederhana yaitu adanya cara cash on delivery (COD). Dimana COD merupakan metode pembayaran yang umumnya dilakukan bila antara penjual dan pembeli berada dalam satu kota atau pada jarak dekat sehinggah penjual bisa langsung menerima pembayaran secara tunai saat barang diterima pembeli. Namun cara ini masih memiliki kekurangan baik untuk penjual dan pembeli (Jihan Alhabsyi dkk, 2014).Masalah yang sering terjadi pada COD yaitu pada saat tranksaksi dilakukan dilokasi, dimana belum mengetahui komdisi tempat COD yang strategis dari segi keamanan maupun kelayakannya secara pasti, selain itu terdapat maslah dari faktor pemilihan lokasi COD yang ditentukan sepihak, sehingga resiko kriminalitas menjadi semakin besar dan dapat mengancam keselamatan penjual maupun pembeli (Labib, 2018).

Berdasarkan tabel omzet penjualan, dapat dilihat bahwa semua pihak yang terlibat didalam E-Commerce mendapat keuntungan yang lebih besar. Berdasarkan wawancara yang dilakukan dengan bapak Abdul Wahab, pendapatan dari usahanya meningkat dari 4- 5 juta per bulan menjadi 4,8 juta- 6 juta perbulan, yang artinya setiap bulan mengalami peningkatan sekitar 20\%. Pendapatan dari ibu Hasryanti mengalami peningkatan sekitar 30\% yang pendapatan dari 4-5 juta menjadi 5,2 juta-6,5 juta per bulan. Sementara berdasarkan wawancara dari bapak Hendra, pendapatan dari usahanya meningkat dari 7,5 juta menjadi 9 juta per bulan, yang artinya setiap bulan mengalami peningkatan sekitar 30\%. Pendapatan dari ibu Sry Mulya mengalami 
peningkatan sekitar $20 \%$ yang pendapatan dari 1 juta menjadi 1,2 juta per bulan. Sedangkan berdasarkan wawancara dari ibu Siti Fajriani, pendapatan usahanya meningkat dari 6-20 juta menjadi 7,5-25 juta per bulan, yang artinya setiap bulan mengalami peningkatan sekitar $25 \%$. Hal ini menunjukkan bahwa pengunaan $E$ Commerce dapat meningkatkan omzet penjualan para pelaku UMKM sebesar 20\%$30 \%$. Hal ini relevan dengan hasil penelitian yang dilakukan oleh Maryama (2013), bahwa manfaat terbesar dari pemanfaatan $E$-Commerce adalah meningkatkan omzet penjualan sebesar $31 \%$.

\section{KESIMPULAN}

Berdasarkan hasil wawancara dan pembahasan yang telah diuraikan maka penulis memiliki beberapa kesimpulan atas hasil penelitian ini yaitu sebagai berikut:

1. Dari hasil wawancara telah ditemukan bahwa dampak positif dengan adanya pengguanaan $E$-Commerce yaitu, toko yang dapat diakses 24 jam, memberikan keamanan dan kemudahan dalam proses tranksaksi, mempermuda promosi sehingga dapat membantu komunikasi lebih cepat dengan pelanggan dan dapat mengakses pasar global serta dapat memuaskan pelanggan dan tentunya dapat meningkatkan omzet penjualan.

2. Dari hasil wawancara telah ditemukan bahwa dengan penggunaan $E$-Commerce juga memberikan dampak negative yaitu apabila barang rusak barang bisa dicansel dan mengakibatkan adanya rugi pada ongkos kirim dan packing, banyaknya saingan, adanya biaya admin yang dibebankan kepada pembeli dan penjual, adanya sistem COD yang membuat penjual merasa dirugikan karena dana dilepas setelah barang tiba.

3. Dari hasil wawancara telah ditemukan bahwa dengan penggunaan $E$-Commerce dapat meningkatkan omzet penjualan $20 \%-30 \%$.

\section{DAFTAR PUSTAKA}

Anonimius, 2015. Tim Kementrian Koperasi dan UMKM 2015, Rencana Strategis Kementrian Koperasi dan Usaha Kecil Dan Menengah Republik Indonesia Tahun 2015-2019, Kementrian Koperasi dan Ukm, Jakarta

Caniago, 2002. Strategi memajukan usaha kecil dan menengah. Jakarta: Pustaka Fatmariani, 2011. Pengaruh Adopsi Informasi.

Hendriani, 2012. Peran UMKM Dalam Perekonomian Teknologi Indonesia Open Source E-Commerce Terhadap Kinerja UMKM dengan Faktor-Faktor Technology Acceptance Model (TAM) Sebagai Moderating Variabel. Jurnal Teknomatika Vol. 1 No. 1 Palembang STIMIK PalComTech.

Karagozoglu, N, and Lindell, 2004. Electronic Commerce Strategy, Operations, and Performance in Small and Medium Sized Enterprises, Journal of Small Business and Enterprises Development.

Maulana. Miftah Shabur.dkk.2015. Implementasi E-Commerce Sebagai Media Penjualan Online (Studi Kasus Pada Tokoh Pastbrikkota Malang). Jurnal Administrasi Bisnis.Fakultas Ilmu AdministrasiUniversitas Brawijaya Malang. Vol.29 No.1

Rahmidani Rose, 2015. Pengunaan E-Commerce Dalam Bisnis Sebagai Sumber Keunggulan Bersaing Perusahaan. Jurnal.

Sevtian, F. I. 2011. Pengaruh E-commerce Terhadap Tingkat Volume Penjualan Sandal Kelom Geulis Di CV Kelomgeulis Tasikmalaya. Skripsi, Jakarta: FPEB Universitas Pendidika Indonesia. 
Entrepreneurship Study (fE3S)

Swasta, 2005. Manajemen pemasaran modern. Yokyakarta: Liberty. 